\title{
DEVELOPMENT AND VALIDATION OF NEW SPECTROPHOTOMETRIC METHODS FOR ESTIMATION OF ANTIPSYCHOTIC DRUG ASENAPINE MALEATE IN PURE AND DOSAGE FORMS
}

\author{
RAGAA EL-SHEIKH ${ }^{1}$, AHLAM E. ABD ELLATEIF², ESRAA AKMAL ${ }^{1}$, AYMAN A. GOUDA ${ }^{1,3^{*}}$
}

${ }^{1}$ Department of Chemistry, Faculty of Science, Zagazig University, Zagazig, 44519, Egypt, ${ }^{2}$ Department of Chemistry, Toxicology and Nutritional Deficiency, Agriculture Research Center, Animal Health Research Institute, Zagazig, Egypt, ${ }^{3}$ Department of Occupational Health, Faculty of Public Health and Health Informatics, Umm AL-Qura University, Makkah, Saudi Arabia

Email: aymangouda77@gmail.com

Received: 30 Mar 2020, Revised and Accepted: 10 May 2020

\section{ABSTRACT}

Objective: Three sensitive, simple, precise, reproducible, and validated spectrophotometric methods have been developed for the determination of anti-psychotic drug (asenapine maleate) in pure and pharmaceutical dosage forms.

Methods: The methods are based on the formation of yellow-colored ion-pair complex between asenapine maleate and three acid dyes, namely, bromocresol purple (BCP), bromophenol blue (BPB) and bromothymol blue (BTB) with absorption maxima at 410,414 and 416 nm, respectively. Several parameters such as $\mathrm{pH}$, buffer type and volume, reagent volume, the sequence of addition and effect of extracting solvent were optimized.

Results: Under the optimum experimental conditions, beer's law is obeyed over the concentration ranges of 1.0-20, 1.0-14, and 1.0-16 $\mu \mathrm{g} / \mathrm{ml}$ for BCP, BPB and BTB, respectively, with good correlation coefficients (0.9994-0.9998). The apparent molar absorptivity and Sandell's sensitivity values are reported for all methods. The limit of detection (LOD) and the limit of quantification (LOQ) values are found to be $0.27,0.30$, and 0.25 $\mu \mathrm{g} / \mathrm{ml}$ and $0.90,1.0$, and $0.83 \mu \mathrm{g} / \mathrm{ml}$ for BCP, BPB and BTB, respectively. The stoichiometric ratio of the formed ion-pair complexes was found to be 1:1 (drug: reagent) for all methods, as deduced by Job's method of continuous variation.

Conclusion: The proposed methods were successfully applied for the determination of asenapine maleate in pharmaceutical formulations with good accuracy and precision. Statistical comparison of the results was performed using Student's t-test and variance ratio F-test at the 95\% confidence level and there was no significant difference between the reported and proposed methods regarding accuracy and precision. Further, the validity of the proposed methods was confirmed by recovery studies via standard addition technique in accordance with ICH guidelines.

Keywords: Asenapine maleate, Ion-pair complex, Spectrophotometry, Method validation, Dosage forms

(C) 2020 The Authors. Published by Innovare Academic Sciences Pvt Ltd. This is an open access article under the CC BY license (http://creativecommons.org/licenses/by/4.0/) DOI: http://dx.doi.org/10.22159/ijap.2020v12i4.37676. Journal homepage: https://innovareacademics.in/journals/index.php/ijap

\section{INTRODUCTION}

Asenapine Maleate (ASP) is chemically designated as (3aRS,12bRS)rel-5-Chloro-2,3,3a,12b-tetrahydro-2-methyl-1H-dibenz $\quad(2,3: 6,7)$ oxepino4,5-c] pyrrole maleate (fig. 1) [1]. ASP is an atypical antipsychotic drug and it was approved for use in the USA in for the treatment of schizophrenia and bipolar disorder. It shows a high affinity for numerous receptors like serotonin, adrenergic, dopamine, histamine [2].

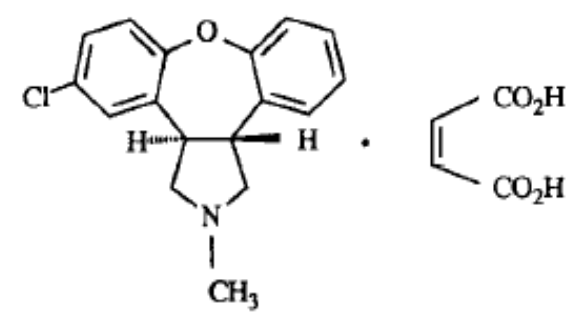

Fig. 1: The chemical structure of asenapine maleate (ASP)

The literature survey revealed that many methods were described for the determination of ASP in pure, tablet dosage forms and biological fluids such as spectrofluorimetry [3], highperformance liquid chromatography (HPLC) [4-15], stability indicating HPLC methods [16-21], thin layer chromatography [22], gas chromatography [23], potentiometry [24] and titrimetric method [25]. Most of these reported methods are either not appropriately sensitive or tedious and utilized expensive instruments that are not available in most quality control laboratories.

Visible spectrophotometry is considered as the most convenient analytical technique in most quality control and clinical laboratories, hospitals and pharmaceutical industries for the assay of different classes of drugs in pure form, pharmaceutical formulations and biological samples, due to its simplicity, less expensive, less time consuming and reasonable sensitivity with significant economic advantages.

To the best of our knowledge, there are few methods that have been reported for the quantification of ASP in commercial dosage forms using a spectrophotometric technique [26-31] (table 1). However, these previously reported methods suffer from one or more disadvantage such as poor sensitivity, depending on critical experimental variables, few methods require a rigid $\mathrm{pH}$ control and tedious and time-consuming liquid-liquid extraction step; some other methods have a relatively narrow dynamic linear range, involve a heating step, and/or use of expensive reagent or large amounts of organic solvents. For these reasons, it was worthwhile to develop a new, simple, cost-effective and selective spectrophotometric method for the determination of ASP their pharmaceutical dosage forms.

The aim of the present work is to develop simple, sensitive, accurate, precise, low-cost and validated extractive spectrophotometric methods for the determination of ASP in pure and dosage forms. The proposed methods are based on the ability of ASP to form stable ion-pair complexes with bromocresol purple (BCP), bromophenol blue (BPB) and bromothymol blue (BTB). No interference was observed in the assay of ASP from common excipients in levels found in dosage forms. These methods are validated by statistical data. 
Table 1: Comparison between the reported spectrophotometric methods and the present method for the determination of ASP

\begin{tabular}{|c|c|c|c|c|c|}
\hline Method & Wavelength (nm) & $\begin{array}{l}\text { Beer's law } \\
(\mu \mathrm{g} / \mathrm{ml})\end{array}$ & $\begin{array}{l}\text { Molar absorptivity } \\
\text { (L/mol. cm) }\end{array}$ & $\begin{array}{l}\text { LOD } \\
(\mu \mathrm{g} / \mathrm{ml})\end{array}$ & Reference \\
\hline \multirow[t]{3}{*}{ UV-spectroscopy } & 215 & $5.0-20$ & NA & 0.929 & \multirow[t]{3}{*}{ [26] } \\
\hline & 230 & $5.0-20$ & NA & 0.471 & \\
\hline & $\begin{array}{l}\text { Absorption ration at } \\
215 \text { and } 230\end{array}$ & $5.0-20$ & NA & 1.75 & \\
\hline \multicolumn{6}{|l|}{ UV-spectroscopy } \\
\hline a- Fixed wavelength & 269 & $10-60$ & $6.39 \times 10^{3}$ & 0.0122 & \multirow[t]{2}{*}{ [27] } \\
\hline b- Area under curve & $263-274$ & $10-60$ & $6.39 \times 10^{3}$ & 0.0122 & \\
\hline UV-spectrophotometry & 270 & $10-60$ & NA & 1.4 & [28] \\
\hline UV-spectrophotometry & 220 & $2.0-10$ & $1.1 \times 10^{4}$ & 0.20381 & [29] \\
\hline UV-spectrophotometry & 270 & $1.0-90$ & NA & NA & [13] \\
\hline Bromocresol green & 415 & $5.0-30$ & NA & 0.39 & {$[30]$} \\
\hline Folin ciocalteu (FC) & 769 & $4.0-20$ & $7.5 \times 10^{4}$ & 0.271 & {$[31]$} \\
\hline Bromocresol purple (BCP) & 410 & $1.0-16$ & $2.136 \times 10^{4}$ & 0.27 & \multirow{3}{*}{$\begin{array}{l}\text { Proposed } \\
\text { work }\end{array}$} \\
\hline Bromophenol blue (BPB) & 414 & $1.0-14$ & $2.607 \times 10^{4}$ & 0.30 & \\
\hline Bromothymol blue (BTB) & 416 & $1.0-20$ & $1.539 \times 10^{4}$ & 0.25 & \\
\hline
\end{tabular}

NA: not available.

\section{MATERIALS AND METHODS}

\section{Instruments}

All absorption spectra were made using Varian UV-Vis spectrophotometer (Cary 100 Conc., Australia) equipped with 10 $\mathrm{mm}$ quartz cell was used for absorbance measurements. This spectrophotometer has a wavelength accuracy of $\pm 0.2 \mathrm{~nm}$ with a scanning speed of $200 \mathrm{~nm} / \mathrm{min}$ and a bandwidth of $2.0 \mathrm{~nm}$ in the wavelength range of $200-900 \mathrm{~nm}$. The $\mathrm{pH}$ values of different buffer solutions were checked using a Hanna $\mathrm{pH}$-meter instrument $\mathrm{(pH}$ 211) (Romania) equipped with a combined glass-calomel electrode.

\section{Materials and reagents}

All reagents, chemicals and solvents used were of analytical or pharmaceutical grade and all solutions were prepared fresh daily. Bidistilled water was used throughout the investigation.

Pure sample of ASP was kindly supplied by Hikma Pharma SAE, $6^{\text {th }}$ October, Egypt, with a purity of $99.60 \pm 1.20 \%$ by applying the reported method [30]. Asenadia tablets, labeled to contain $10 \mathrm{mg}$ ASP per sublingual tablet, a product of Western Pharmaceutical Industries Company, Cairo, Egypt. Asenapine-Hikma Pharma tablets, labeled to contain 5.0 mg ASP per sublingual tablet, a product of Hikma Pharma SAE, $6^{\text {th }}$ October, Egypt were purchased from local pharmacies.

\section{Preparation of stock standard solution}

Stock standard solutions $(100 \mu \mathrm{g} / \mathrm{ml})$ and $\left(1.0 \times 10^{-3} \mathrm{~mol} / \mathrm{l}\right)$ of ASP were prepared by dissolving 10 and $40.18 \mathrm{mg}$ of pure ASP in the least amount of methanol and further diluted with bidistilled water to the mark in a $100 \mathrm{ml}$ volumetric flask. The standard solutions were stable for at least $7.0 \mathrm{~d}$ when kept in the refrigerator. Serial dilution with the same solvent was performed to obtain the appropriate concentration range.

\section{Reagents}

BCP, BPB and BTB (BDH Chemicals LTD, Poole, England) and used without further purification. Stock solutions $(0.1 \%, \mathrm{w} / \mathrm{v})$ or $\left(1.0 \times 10^{-3} \mathrm{~mol} / \mathrm{l}\right)$ of reagents were prepared by dissolving the appropriate weight of each reagent in $10 \mathrm{ml}$ of $96 \%$ ethanol and diluted to $100 \mathrm{ml}$ with bidistilled water. These solutions were kept in the refrigerator.

Series of buffer solutions of NaOAc-HCl $(\mathrm{pH}=1.99-4.92)$, NaOAc$\mathrm{AcOH}(\mathrm{pH}=3.4-5.6)$ and potassium hydrogen phthalate- $\mathrm{HCl}(\mathrm{pH}=2.0$ 7.0) were prepared by following the standard methods [32]. The $\mathrm{pH}$ of each solution was adjusted to an appropriate value by the addition of $0.2 \mathrm{~mol} / \mathrm{l}$ hydrochloric acid or sodium hydroxide with the help of the $\mathrm{pH}$ meter. Freshly prepared solutions were always employed. Chloroform, methylene chloride, and carbon tetrachloride were obtained from (BDH Chemicals Ltd., Poole, England) and anhydrous sodium sulfate was obtained from (Prolabo).

\section{General recommended procedure}

Accurately measured aliquots $(0.1-2.0 \mathrm{ml})$ of standard ASP solution $(100 \mu \mathrm{g} / \mathrm{ml})$ was transferred into $10 \mathrm{ml}$ measuring flasks. $3.0 \mathrm{ml}$ $\mathrm{NaOAc}-\mathrm{AcOH}$ buffer at the optimum pH 4.0, 3.5 and 4.0 using BCP, $\mathrm{BPB}$ and BTB, respectively, were added. Then, $2.0 \mathrm{ml}$ of the BCP, BPB and BTB $(0.1 \%, \mathrm{w} / \mathrm{v})$ was added and the volume was completed to $10 \mathrm{ml}$ with bidistilled water. The formed ion associate complexes were extracted with $10 \mathrm{ml}$ methylene chloride. The solution was shaking for $2.0 \mathrm{~min}$, then allowed to stand for clear separation of the two phases and the methylene chloride layer was passed through anhydrous sodium sulfate. The absorbance of the yellow-colored ion-pair complexes was measured at 410, 414 and $416 \mathrm{~nm}$ using $\mathrm{BCP}, \mathrm{BPB}$ and BTB, respectively, against the corresponding reagent blank similarly prepared. All measurements were made at room temperature $\left(25 \pm 2{ }^{\circ} \mathrm{C}\right)$. In the three proposed methods, a standard curve was prepared by plotting the absorbance values versus concentrations of ASP to calculate the amount of drug in unknown analyte samples.

\section{Applications for dosage forms (tablets)}

Twenty tablets containing ASP were finely pulverized and weighed. A weighed quantity of the powdered tablets equivalent to $10 \mathrm{mg}$ of ASP was transferred into a $100 \mathrm{ml}$ volumetric flask, about $20 \mathrm{ml}$ of methanol was added and the flask was sonicated for $30 \mathrm{~min}$. The volume was completed to the mark with bidistilled water, mixed well and filtered through a Whatman No.1 filter paper into $100 \mathrm{ml}$ volumetric flask, discarding the first $10 \mathrm{ml}$; then, the conical flask was washed with bidistilled water. The wash was added to the same volumetric flask, and then the flask was made up to volume with bidistilled water. Aliquots containing ASP in the final concentration ranges were analyzed as described under "General recommended procedure". The concentration of ASP was determined either from the calibration curve or using the corresponding regression equation. The method of standard addition was used for the accurate determination of ASP content.

\section{Stoichiometric relationship}

The stoichiometric ratios of the ion-associates formed between ASP and the reagents were determined by applying the continuous variation [33] and the molar ratio [34] methods at the optimum wavelengths. In the continuous variation method, equimolar solutions were employed: a $1.0 \times 10^{-4} \mathrm{~mol} / \mathrm{l}$ standard solution of ASP and $1.0 \times 10^{-4} \mathrm{~mol} / \mathrm{l}$ solution of dye were used. A series of solutions was prepared in which the total volume of ASP and the dye was kept at $2.0 \mathrm{ml}$. The drug and reagent were mixed in 
various complementary proportions $(0.2: 1.8,0.4: 1.6,0.6: 1.4$, $0.8: 1.2,1.0: 1.0,1.2: 0.8,1.4: 0.6,1.6: 0.4,1.8: 0.2)$ and completed to volume in a $10 \mathrm{ml}$ calibrated flask with the appropriate solvent for extraction following the above mentioned procedure. In the molar ratio method, the concentration of ASP is kept constant to $1.0 \mathrm{ml}$ of $\left(1.0 \times 10^{-4} \mathrm{~mol} / \mathrm{l}\right)$ while that of dye $\left(1.0 \times 10^{-4} \mathrm{~mol} / \mathrm{l}\right)$ is regularly varied $(0.2-2.4 \mathrm{ml})$. The absorbance of the prepared solutions was measured at optimum condition and at the optimum wavelength for each complex.

\section{RESULTS AND DISCUSSION}

\section{Absorption spectra}

The nitrogenous drugs are present in positively charged protonated forms and anionic dyes present mainly in anionic form at $\mathrm{pH} \geq 2.5$. So, when treated with an acid dye at acidic $\mathrm{pH}$ using buffer solutions, a yellow ion-pair complex which is extracted with methylene chloride is formed. The absorption spectra of the ion-pair complexes, which were formed between ASP and reagents, were measured in the range $350-550 \mathrm{~nm}$ against the blank solution and the maximum absorbances were measured at wavelengths 410,414 , and $416 \mathrm{~nm}$ using BCP, BPB, and BTB, respectively.

\section{Optimum reaction conditions for complex formation}

The optimization of the methods was carefully studied to achieve the complete reaction formation, highest sensitivity and maximum absorbance. Reaction conditions of the ion-pair complex were found by studying with preliminary experiments such as $\mathrm{pH}$ of the buffer, the type of organic solvent, volumes of the dye, reaction time and temperature for the extraction of ion-pair complexes.

\section{Effects of $\mathrm{pH}$}

It was observed that the effective extraction of the complex depends on the type of the buffer used and its $\mathrm{pH}$ value. The effect of $\mathrm{pH}$ was studied by extracting the colored complexes in the presence of various buffers such as $\mathrm{NaOAc}-\mathrm{HCl}(\mathrm{pH}=2.0-4.5)$, $\mathrm{NaOAc}-\mathrm{AcOH}$ $(\mathrm{pH}=2.8-5.5)$ and potassium hydrogen phthalate- $\mathrm{HCl}(\mathrm{pH}=3.0-6.0)$. It is evident that the maximum color intensity and maximum absorbance were found in $\mathrm{NaOAc}-\mathrm{AcOH}$ buffer. It is evident that the maximum absorbances of the ion pair complexes were obtained at $\mathrm{pH} 4.0,3.5$, and 4.0 for BCP, BPB and BTB methods, respectively (fig. 2). Buffer volume was determined by applying the same experiment and variation the volume regularly $(0.5-5.0 \mathrm{ml})$. The higher absorbance value and reproducible results were obtained by using $3.0 \mathrm{ml}$ of acetate buffer solutions.

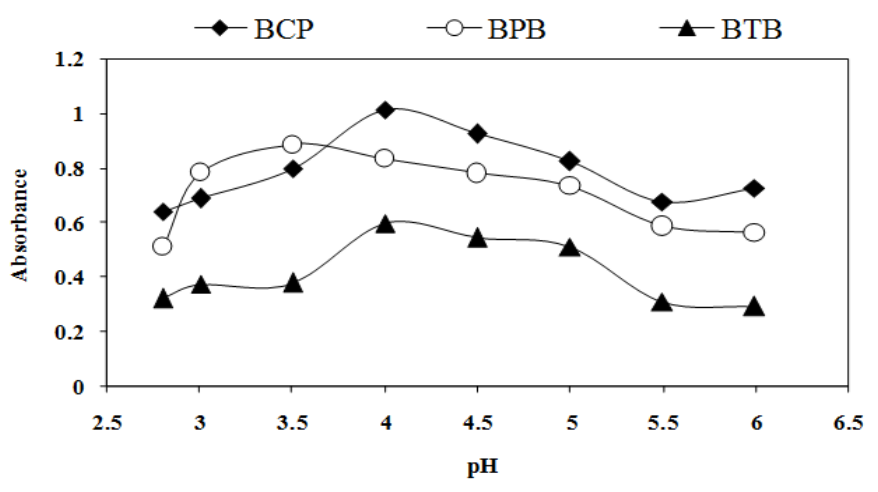

Fig. 2: Effect of $\mathrm{pH}$ of buffer solution on the ion pair complex formation between $(20,14$ and $16 \mu \mathrm{g} / \mathrm{ml})$ ASP and $(0.1 \%$, w/v) BCP, BPB and BTB reagents, respectively, $(\mathrm{N}=3.0)$

\section{Effect of reagent concentration}

The effect of the reagent was studied by measuring the absorbances of solutions containing a fixed concentration of ASP and various volumes of the $\mathrm{BCP}, \mathrm{BPB}$ or $\mathrm{BTB}(0.1 \%, \mathrm{w} / \mathrm{v})$ reagents in the range of $(0.5-4.0 \mathrm{ml})$. The results showed that the absorbance of the extracted ion-pair increased by increasing the BCP, BPB or BTB volume till $2.0 \mathrm{ml}$. So, the maximum color intensity of the complex was achieved with $2.0 \mathrm{ml}$ of $(0.1 \%, \mathrm{w} / \mathrm{v})$ of each reagent solution. Although a larger volume of the reagent had no pronounced effect on the absorbance of the formed ionpair complexes (fig. 3).

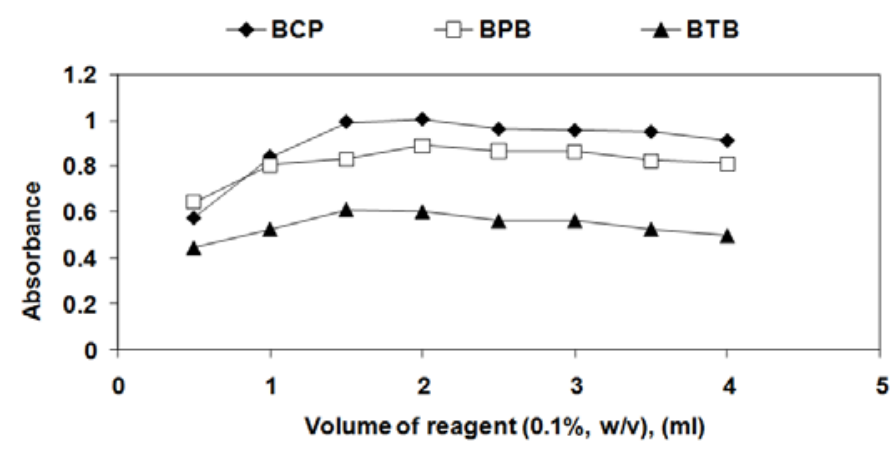

Fig. 3: Effect of volume of $(0.1 \%, w / v)$ BCP, BPB and BTB reagent on the ion pair complex formation with (20, 14 and $16 \mu \mathrm{g} / \mathrm{ml})$ ASP, respectively, $(\mathrm{N}=3.0)$

\section{Choice of extracting solvent}

The effect of several organic solvents viz., chloroform, carbon tetrachloride, dichloromethane and diethyl ether were studied for effective extraction of the colored species from the aqueous phase (fig. 4). Dichloromethane was found to be the most suitable solvent for the extraction of colored ion-pair complexes for all reagents 
quantitatively. Experimental results indicated that double extraction with total volume $10 \mathrm{ml}$ dichloromethane, yielding maximum absorbance intensity, stable absorbance and considerably lower extraction ability for the reagent blank and the shortest time to reach the equilibrium between both phases.

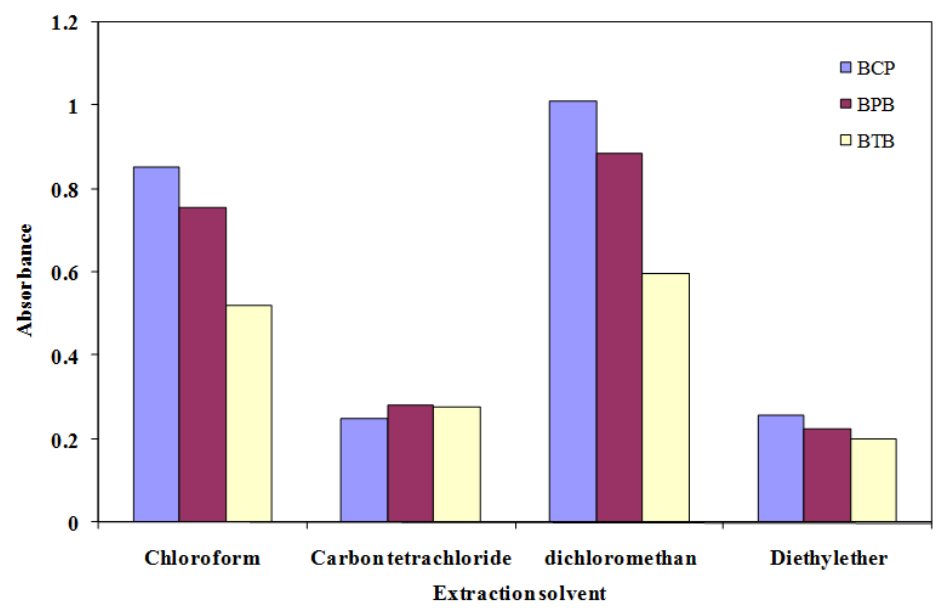

Fig. 4: Effect of extraction solvent on the ion pair complex formation of ASP with dyes at the optimum conditions

\section{Effect of shaking time and temperature}

The optimum shaking time was investigated by shaking from $0.5-$ $5.0 \mathrm{~min}$ at ambient temperature $\left(25 \pm 2{ }^{\circ} \mathrm{C}\right)$. Maximum and constant absorbance values were obtained when extracted after $2.0 \mathrm{~min}$ of shaking for all complexes. Therefore, a shaking time of $2.0 \mathrm{~min}$ was maintained throughout the experiment. The effect of temperature on colored complexes was studied by measuring the absorbance values over the temperature range $20-35{ }^{\circ} \mathrm{C}$. It was found that the absorbance of the colored ion-pair complex was constantly up to 30 ${ }^{\circ} \mathrm{C}$. At higher temperatures, the drug concentration was found to increase due to the volatile nature of dichloromethane. Therefore, the temperature chosen was room temperature $\left(25 \pm 2{ }^{\circ} \mathrm{C}\right)$ as the best temperature for the determination of ASP in bulk and pharmaceutical formulations. The absorbance of the complexes remains stable for at least $12 \mathrm{~h}$ at room temperature.

\section{Composition of the ion-pair complexes}

The molar ratio of the ion pair complexes (ASP: dye) was determined by the continuous variations and molar ratio methods (figs. 5 and 6). The results indicate that the molar ratio of (ASP: dye) is (1:1) ion-pair complex are formed through the electrostatic attraction between the positively charged ASP+and negatively charged dye, (BCP-, $\mathrm{BPB}^{-}$, and $\left.\mathrm{BTB}^{-}\right)$. The extraction equilibrium can be represented as follows:

$$
\operatorname{ASP}_{(\mathrm{aq})}^{+}+\mathrm{D}_{(\mathrm{aq})}^{-} \longleftrightarrow \operatorname{ASP}^{+} \mathrm{D}_{(\mathrm{aq})}^{-} \longleftrightarrow \mathrm{ASP}^{+} \mathrm{D}_{(\text {org })}^{-}
$$

Where $\mathrm{ASP}^{+} \mathrm{CndD}^{-}$represent the protonated drug and the anion of the dye $\left(\mathrm{BCP}^{-}, \mathrm{BPB}^{-}\right.$or $\left.\mathrm{BTB}^{-}\right)$, respectively, and the subscript (aq) and (org) refer to the aqueous and organic phases, respectively (scheme 1).<smiles>CN1C[C@@H]2c3cc(Cl)ccc3Oc3ccccc3[C@@H]2C1</smiles><smiles>O=C(O)/C=C\C(=O)O</smiles><smiles>CC1=CC(=C(c2cc(C)c(O)c(Br)c2)c2ccccc2[S+](=O)(=O)[O-])C=C(Br)C1=O</smiles><smiles>C[NH+]1C[C@@H]2c3cc(Cl)ccc3Oc3ccccc3[C@@H]2C1</smiles><smiles>CCCCCCCCC(=O)O</smiles><smiles>CC1=CC(=C(c2cc(C)c(O)c(Br)c2)c2ccccc2S(C)(=O)=O)C=C(Br)C1=O</smiles>

ASP - BCP ion-pair complex 


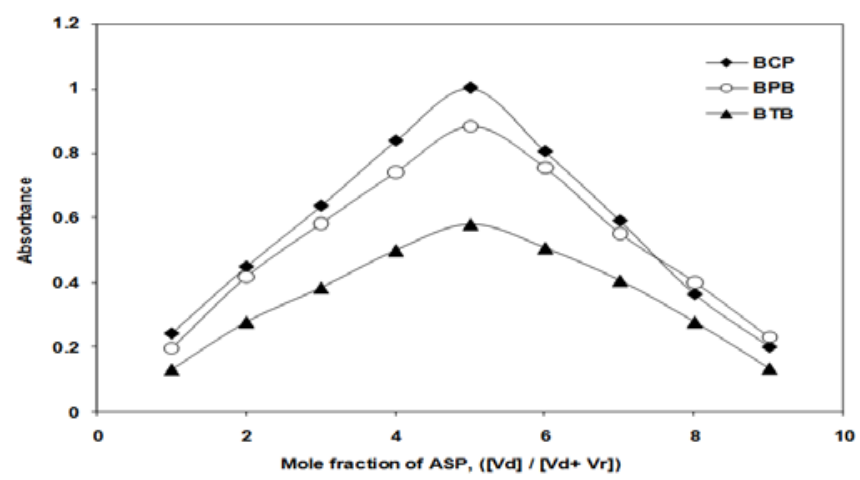

Fig. 5: Job's method of continuous variation graph for the reaction of ASP with $B C P, B P B$ and $B T B,[d r u g]=[d y e]=\left(1.0 \times 10^{-4} \mathrm{~mol} / 1\right)(\mathrm{N}=3.0)$

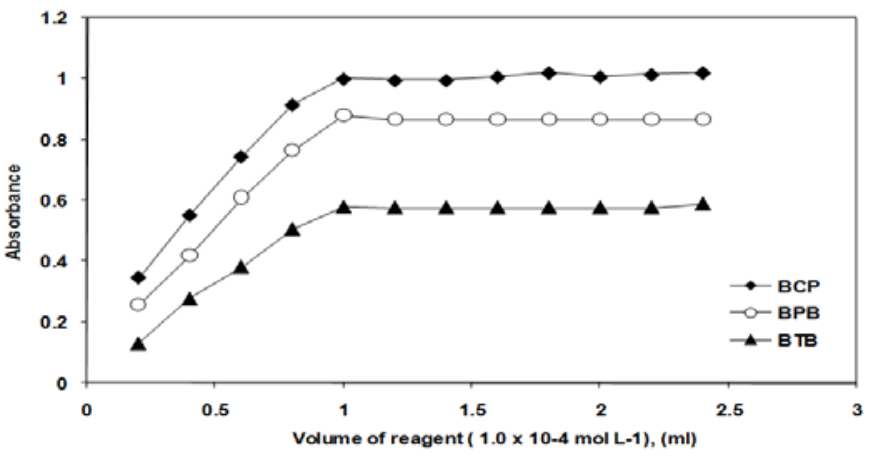

Fig. 6: Mole ratio plots for the ion-association complexes of ASP $\left(1.0 \times 10^{-4} \mathrm{~mol} / \mathrm{l}\right)$ with various volumes of reagent solution $\left(1.0 \times 10^{-4}\right.$ $\mathrm{mol} / \mathrm{l}$ ) at the optimum conditions

\section{Method of validation}

\section{Linearity}

At described experimental conditions for ASP determination, standard calibration curves with reagents were constructed by plotting absorbance vs. concentration of ASP. The statistical parameters were given in the regression equations calculated from the calibration graphs $\mathrm{A}=\mathrm{aC}+\mathrm{b}$, where $\mathrm{A}$ is the absorbance and $\mathrm{C}$ is the concentration in $\mu \mathrm{g} / \mathrm{ml}$. The linearity of calibration graphs was proved by the high values of the correlation coefficient $(r)$ and the small values of the $y$ intercepts of the regression equations. The apparent molar absorptivity of the resulting colored ion-pair complexes and relative standard deviation of response factors for each proposed spectrophotometric method was also calculated and recorded in table 2. The molar absorptivity of $\mathrm{BPB}>\mathrm{BCP}>\mathrm{BTB}$ ion-pair complexes.

\section{Sensitivity}

The limits of detection (LOD) and quantitation (LOQ) for the proposed methods were calculated using the following equation $[35,36]$ :

$$
\text { LOD }=3 s / k \text { and }
$$$$
\mathrm{LOQ}=10 \mathrm{~s} / \mathrm{k}
$$

Wheres is the standard deviation of ten replicate determinations values of the reagent blank and $\mathrm{k}$ is the sensitivity, namely the slope of the calibration graph. In accordance with the formula, LOD was found to be $0.27,0.30$, and $0.25 \mu \mathrm{g} / \mathrm{ml}$ for BCP, BPB and BTB methods, respectively.

According to this equation, $\mathrm{LOQ}$ was found to be $0.90,1.0$, and 0.83 $\mu \mathrm{g} / \mathrm{ml}$ for BCP, BPB and BTB methods, respectively.

Table 2: Statistical analysis of calibration graphs and analytical data in the determination of ASP using the proposed methods

\begin{tabular}{|c|c|c|c|}
\hline Parameters & BCP & BPB & BTB \\
\hline Wavelengths $\lambda_{\max }(\mathrm{nm})$ & 410 & 414 & 416 \\
\hline Beer's law limits $(\mu \mathrm{g} / \mathrm{ml})$ & $1.0-20$ & $1.0-14$ & $1.0-16$ \\
\hline Molar absorptivity $\varepsilon,(\mathrm{L} / \mathrm{mol} . \mathrm{cm}) \times 10^{4}$ & 2.136 & 2.607 & 1.539 \\
\hline Sandells sensitivity $\left(\mathrm{ng} / \mathrm{cm}^{2}\right)$ & 18.81 & 15.41 & 26.10 \\
\hline \multicolumn{4}{|l|}{ Regression equation ${ }^{a}$} \\
\hline Intercept $(a)$ & 0.0085 & 0.0054 & 0.0052 \\
\hline Standard deviation of intercept $(\mathrm{Sa})$ & 0.012 & 0.007 & 0.009 \\
\hline Slope (b) & 0.0499 & 0.0628 & 0.0365 \\
\hline Standard deviation of slope $(S b)$ & 0.005 & 0.005 & 0.004 \\
\hline Correlation coefficient $\left(r^{2}\right)$ & 0.9998 & 0.9994 & 0.9996 \\
\hline $\operatorname{LOD}(\mu \mathrm{g} / \mathrm{ml})^{\mathrm{b}}$ & 0.27 & 0.30 & 0.25 \\
\hline LOQ $(\mu \mathrm{g} / \mathrm{ml})^{\mathrm{b}}$ & 0.90 & 1.0 & 0.83 \\
\hline mean \pm SD & $99.79 \pm 0.80$ & $100.25 \pm 0.85$ & $99.85 \pm 0.93$ \\
\hline RSD\% (N=6) & 0.80 & 0.85 & 0.93 \\
\hline $\mathrm{RE} \%$ & 0.84 & 0.89 & 0.98 \\
\hline t-test ${ }^{c}$ & 0.29 & 0.99 & 0.37 \\
\hline F-test ${ }^{c}$ & 2.25 & 1.99 & 1.66 \\
\hline
\end{tabular}

${ }^{\mathrm{a}} \mathrm{A}=\mathrm{a}+\mathrm{bC}$, where $\mathrm{C}$ is the concentration in $\mu \mathrm{g} \mathrm{ml}^{-1}, \mathrm{~A}$ is the absorbance units, bOD, limit of detection; LOQ, the limit of quantification; $\varepsilon$, molar absorptivity, theoretical values of $\mathrm{t}$ and $\mathrm{F}$ at $\mathrm{P}=0.05$ are 2.571 and 5.05 , respectively. 


\section{Accuracy and precision}

In order to evaluate the accuracy and precision of the proposed methods, solutions containing three different concentrations of ASP were prepared and the assay procedure was analyzed in six replicates, and percentage relative standard deviation (RSD\%) values were obtained within the same day to evaluate the repeatability (intra-day precision) and over five different days to evaluate intermediate precision (inter-day precision). The percentage relative error (RE\%) was calculated using the following equation:

$$
\mathbf{R E} \%=\frac{(\text { Found }- \text { Added })}{\text { Added }} \times 100
$$

The analytical results of intra-day and inter-day precision (RSD\%) and accuracy (RE\%) were summarized in table 3 . These results of accuracy and precision show that the proposed methods have good repeatability and reproducibility.

Table 3: Intra-day and Inter-day precision and accuracy data for ASP obtained by the proposed methods

\begin{tabular}{|c|c|c|c|c|c|c|c|c|c|}
\hline \multirow[t]{2}{*}{ Method } & \multirow{2}{*}{$\begin{array}{l}\text { Added concentration } \\
(\mu \mathrm{g} / \mathrm{ml})\end{array}$} & \multicolumn{2}{|l|}{ Intra-day } & \multicolumn{6}{|c|}{ Inter-day } \\
\hline & & $\begin{array}{l}\text { Recovery } \\
\%\end{array}$ & $\begin{array}{l}\text { Precision } \\
\text { RSD \% }{ }^{a}\end{array}$ & $\begin{array}{l}\text { Accuracy } \\
\text { RE \% }\end{array}$ & $\begin{array}{l}\text { Confidence } \\
\text { limit b }^{\text {inis }}\end{array}$ & $\begin{array}{l}\text { Recovery } \\
\%\end{array}$ & $\begin{array}{l}\text { Precision } \\
\text { RSD \% a }\end{array}$ & $\begin{array}{l}\text { Accuracy } \\
\text { RE \% }\end{array}$ & $\begin{array}{l}\text { Confidence } \\
\text { limit b }^{\text {b }}\end{array}$ \\
\hline \multirow[t]{3}{*}{ BCG } & 6.0 & 99.00 & 0.48 & -1.0 & $5.94 \pm 0.03$ & 98.90 & 0.53 & -1.10 & $5.934 \pm 0.033$ \\
\hline & 12 & 99.20 & 0.70 & -0.80 & $11.904 \pm 0.087$ & 99.80 & 0.81 & -0.20 & $11.976 \pm 0.102$ \\
\hline & 18 & 100.40 & 1.30 & 0.40 & $18.072 \pm 0.247$ & 99.20 & 0.95 & -0.80 & $17.856 \pm 0.178$ \\
\hline \multirow[t]{3}{*}{ BPB } & 4.0 & 99.20 & 0.67 & -0.80 & $3.968 \pm 0.028$ & 99.10 & 0.50 & -0.90 & $3.964 \pm 0.021$ \\
\hline & 8.0 & 99.00 & 1.10 & -1.0 & $7.92 \pm 0.091$ & 99.30 & 0.47 & -0.70 & $7.944 \pm 0.039$ \\
\hline & 12 & 99.60 & 1.50 & -0.40 & $11.952 \pm 0.188$ & 99.50 & 0.80 & 0.50 & $11.94 \pm 0.1$ \\
\hline \multirow[t]{3}{*}{ ВТВ } & 5.0 & 99.10 & 0.80 & -0.90 & $4.955 \pm 0.042$ & 98.70 & 0.40 & -1.30 & $4.935 \pm 0.021$ \\
\hline & 10 & 100.50 & 0.90 & 0.50 & $10.05 \pm 0.095$ & 99.30 & 0.66 & -0.70 & $9.93 \pm 0.069$ \\
\hline & 15 & 99.70 & 0.75 & -0.30 & $14.955 \pm 0.118$ & 100.80 & 1.20 & 0.80 & $15.12 \pm 0.19$ \\
\hline
\end{tabular}

${ }^{\mathrm{a}}$ Mean of six determination, RSD\%, percentage relative standard deviation; RE\%, percentage relative error, bConfidence limit at $95 \%$ confidence level and five degrees of freedom $(t=2.571)$.

\section{Robustness and ruggedness}

For the evaluation of the method robustness, some parameters were interchanged; $\mathrm{pH}$, dye concentration, wavelength range, and shaking time. The capacity remains unaffected by small deliberate variations.
Method ruggedness was expressed as RSD\% of the same procedure applied by two analysts and in two different instruments on different days. The results showed no statistical differences between different analysts and instruments, suggesting that the developed methods were robust and rugged (table 4).

Table 4: Results of method robustness and ruggedness expressed as intermediate precision (RSD \%) for ASP-dye ion-pair complex

\begin{tabular}{|c|c|c|c|c|c|}
\hline \multirow[t]{4}{*}{ Methods } & \multirow{4}{*}{$\begin{array}{l}\text { Nominal concentration } \\
(\mu \mathrm{g} / \mathrm{ml})\end{array}$} & \multicolumn{4}{|c|}{ RSD\% } \\
\hline & & Robu & & Ruggedness & \\
\hline & & \multicolumn{4}{|c|}{ Variable alerted $^{a}$} \\
\hline & & $\mathrm{pH}^{\mathrm{b}}$ & Dye concentration ${ }^{c}$ & Inter-analysts & Inter-instruments \\
\hline \multirow[t]{3}{*}{ ВСР } & 6.0 & 0.80 & 0.75 & 1.20 & 1.10 \\
\hline & 12 & 1.20 & 1.0 & 1.90 & 1.70 \\
\hline & 18 & 2.0 & 1.70 & 2.30 & 2.40 \\
\hline \multirow[t]{3}{*}{ BPB } & 4.0 & 0.65 & 0.90 & 0.85 & 0.70 \\
\hline & 8.0 & 0.90 & 1.50 & 1.30 & 1.60 \\
\hline & 12 & 1.80 & 2.10 & 1.90 & 2.0 \\
\hline \multirow[t]{3}{*}{ BTB } & 5.0 & 0.95 & 1.20 & 1.0 & 0.80 \\
\hline & 10 & 1.70 & 1.80 & 1.10 & 1.80 \\
\hline & 15 & 2.20 & 2.30 & 1.75 & 2.40 \\
\hline
\end{tabular}

aMean of three determinations, ${ }^{b} \mathrm{pH}( \pm 0.2)$, cThe volumes of dye used were $2.0 \pm 0.2 \mathrm{ml}$.

Table 5: Application of the standard addition method for the determination of ASP in dosage forms (tablets) using the proposed methods

\begin{tabular}{|c|c|c|c|c|c|c|}
\hline \multirow[t]{2}{*}{ Method } & \multirow[t]{2}{*}{$\begin{array}{l}\text { Taken drug } \\
(\mu \mathrm{g} / \mathrm{ml})\end{array}$} & \multirow{2}{*}{$\begin{array}{l}\text { Pure drug } \\
\text { added } \\
(\mu g / m l)\end{array}$} & \multicolumn{2}{|c|}{$\begin{array}{l}\text { Asenapine-hikma pharma tablets (5.0 } \\
\mathrm{mg})\end{array}$} & \multicolumn{2}{|c|}{$\begin{array}{l}\text { Asenadia tablets } \\
(10 \mathrm{mg})\end{array}$} \\
\hline & & & $\begin{array}{l}\text { Total found } \\
(\mu \mathrm{g} / \mathrm{ml})\end{array}$ & $\begin{array}{l}\text { Recovery }^{a} \\
(\%) \pm \text { SD }\end{array}$ & $\begin{array}{l}\text { Total found } \\
(\mu \mathrm{g} / \mathrm{ml})\end{array}$ & $\begin{array}{l}\text { Recovery }^{a} \\
(\%) \pm \text { SD }\end{array}$ \\
\hline \multirow[t]{3}{*}{$\overline{\mathbf{B C P}}$} & 5.0 & 5.0 & 9.93 & $99.30 \pm 0.60$ & 9.88 & $98.80 \pm 0.40$ \\
\hline & 5.0 & 10 & 15.075 & $100.50 \pm 0.75$ & 14.93 & $99.53 \pm 0.64$ \\
\hline & 5.0 & 15 & 19.84 & $99.20 \pm 1.10$ & 20.14 & $100.70 \pm 1.50$ \\
\hline \multirow[t]{3}{*}{ ВPB } & 4.0 & 4.0 & 7.92 & $99.00 \pm 0.36$ & 7.95 & $99.70 \pm 0.55$ \\
\hline & 4.0 & 6.0 & 9.98 & $99.80 \pm 0.80$ & 9.95 & $99.50 \pm 0.68$ \\
\hline & 4.0 & 8.0 & 12.05 & $100.42 \pm 1.40$ & 11.88 & $99.00 \pm 1.60$ \\
\hline \multirow[t]{3}{*}{ BTB } & 4.0 & 4.0 & 7.93 & $99.13 \pm 0.70$ & 7.94 & $99.25 \pm 0.65$ \\
\hline & 4.0 & 6.0 & 9.94 & $99.40 \pm 1.30$ & 10.09 & $100.90 \pm 0.80$ \\
\hline & 4.0 & 8.0 & 11.86 & $98.83 \pm 1.90$ & 11.97 & $99.75 \pm 1.20$ \\
\hline
\end{tabular}

aAverage of six determinations. 


\section{Effects of interference}

To assess the usefulness of the method, the effect of diluents, excipients and additives which often accompany ASP in its dosage forms (starch, lactose, glucose, saccharose, talc, sodium chloride, titanium dioxide, and magnesium stearate) was studied. The results indicated that there is no interference from excipients and additives, indicating a high selectivity for determining ASP in its dosage forms.

\section{Applications to dosage forms}

The proposed methods have been successfully applied to the determination of ASP in dosage forms (Asenapine-Hikma Pharma tablets and Asenadia tablets). Six replicates determinations were made. Moreover, to check the validity of the proposed methods, dosage forms were tested for possible interference with standard addition method (table 5). Therefore, it is concluded that the excipients in dosage forms of ASP did not cause any interference in the analysis of ASP. A statistical comparison of the results for the determination of ASP in tablet dosage forms using the proposed and reported methods [30] is shown in table 6. Statistical analysis of the results using Student's t-test for accuracy and F-test for precision revealed no significant difference between the proposed and reported methods at the $95 \%$ confidence level with respect to accuracy and precision [36] (table 6).

Table 6: Results of analysis of tablets by the proposed methods for the determination of ASP and statistical comparison with the reported method [30]

\begin{tabular}{|c|c|c|c|c|}
\hline \multirow[t]{3}{*}{ Samples } & \multicolumn{4}{|c|}{ Recovery $^{\text {a }(\%) \pm S D}$} \\
\hline & \multicolumn{3}{|c|}{ Proposed methods } & \multirow{2}{*}{$\begin{array}{l}\text { Reported } \\
\text { method [30] }\end{array}$} \\
\hline & BCP & BPB & BTB & \\
\hline Asenapine-Hikma Pharma tablets (5.0 mg) & $99.67 \pm 0.72$ & $99.74 \pm 0.71$ & $99.12 \pm 0.29$ & $99.40 \pm 0.54$ \\
\hline$t$-value ${ }^{b}$ & 0.67 & 0.85 & 1.02 & \\
\hline$F$-value ${ }^{b}$ & 1.78 & 1.73 & 3.47 & \\
\hline Asenadia tablets (10 mg) & $99.68 \pm 0.96$ & $99.40 \pm 0.36$ & $99.97 \pm 0.85$ & $99.78 \pm 0.60$ \\
\hline$t$-value ${ }^{b}$ & 0.20 & 1.21 & 0.41 & \\
\hline F-value $b$ & 2.56 & 2.78 & 2.01 & \\
\hline
\end{tabular}

${ }^{a}$ Average of six determinations, bThe theoretical values of $t$ and $F$ are 2.571 and 5.05, respectively at confidence limit at $95 \%$ confidence level and five degrees of freedom $(p=0.05)$.

\section{CONCLUSION}

The proposed methods describe the application of extractive ionpair complex formation reaction with dyes for the quantification of ASP in pure and dosage forms. Compared with the existing spectrophotometric methods, the proposed methods have the advantages of relatively simple, rapid, cost-effective, and more sensitive for determining ASP in pure and dosage forms. Moreover, the proposed methods are free from tedious experimental steps such as heating unlike the previously reported spectrophotometric methods cited earlier. The most attractive feature of these methods is its relative freedom from interference by the usual diluents and excipients in amounts far in excess of their normal occurrence in pharmaceutical formulations. The statistical parameters and the recovery data reveal high precision and accuracy of the proposed methods besides being robust and rugged. Therefore, the validated method could be useful for routine quality control assay of ASP in pure and dosage forms.

\section{FUNDING}

Nil

\section{AUTHORS CONTRIBUTIONS}

Prof. Dr. Ragaa El Sheikh has generated the research idea and interpreted the data and helped to draft the manuscript. Prof. Dr. Wafaa El Sayed Hassan has suggested the research idea and participated in the design of the study. Miss. Esraa Akmal was prepared the solutions, carried out the experiments, interpreted the data and helped to draft the manuscript. Prof. Dr. Ayman A. Gouda helped in check spelling, reducing plagiarism, interpreting the data, reviewed the manuscript and submit the manuscript for publication.

\section{CONFLICTS OF INTERESTS}

The authors confirm that this article content has no conflict of interest.

\section{REFERENCES}

1. Saphris (asenapine) sublingual tablets, FDA drug approval package. Available from: http://www.accessdata.fda.gov/ drugsatfda_docs/nda/2009/022117s000_ChemR.pdf [Last accessed on 11 Feb 2016].
2. Balaraman R, Gandhi H. Asenapine, a new sublingual atypical antipsychotic. J Pharmacol Pharmacother 2010;1:60-1.

3. Ramadan NK, Mohamed TA, Fouad RM, Moustafa AA. Development and validation of stability-indicating spectrophotometric and spectrofluorimetric methods for the determination of asenapine maleate. Der Pharma Chem 2018;10:122-34.

4. Nagarajan G, Shirisha K, Archana Mu, Sravanthi P, Ramana BV. Method development and validation of RP-HPLC method for the determination of new antipsychotic agent asenapine maleate in bulk and in pharmaceutical formulation. Pharm Lett 2012;4:1805-10.

5. Chander P, Mehta T. HPLC-UV method for the determination of asenapine maleate impurities using a solid core C8 column. Thermo Fisher Sci Inc Appl Note 2013;20:739-44.

6. Aarelly K, Thimmaraju MK, Nerella R, Allabotharam S. Method development and validation of asenapine in bulk by RP-HPLC method. J Chem Pharm Res 2012;4:2580-4.

7. Parthasarathi TR, Srinivas TS, Vanitha SMS, Ram S, Basha MM, Rajesh P. Quantitative determination of asenapine maleate using reversed phase-high performance liquid chromatography. Int J Pharma Bio Sci 2012;3:360-6.

8. Geetharam Y, Ramamohan GV, Srikumar PP, Rusyendra GV, Lavanya N. Development and validation of RP-HPLC method for the estimation of asenapine maleate in bulk and pharmaceutical dosage forms. Asian J Pharm Anal Med Chem 2013;1:132-9.

9. De Boer T, Meulman E, Meijering H, Wieling J, Dogterom P, Lass H. Quantification of asenapine and three metabolites in human plasma using liquid chromatography-tandem mass spectrometry with automated -pssasied extraction: application to a phase I clinical trial with asenapine in healthy male subjects. Biomed Chromatogr 2012;26:156-65.

10. De Boer T, Meulman E, Meijering H, Wieling J, Dogterom P, Lass H. Development and validation of automated SPE-HPLC-MS/MS method for the quantification of asenapine, a new antipsychotic agent, and its two major metabolites in human urine. Biomed Chromatogr 2012;26:1461-3.

11. Govindarajan NR, Koulagari S, Methuku A, Podhuturi S. Method development and validation of RP-HPLC method for determination of new antipsychotic agent asenapine maleate in bulk and pharmaceutical formulation. Eurasian J Anal Chem 2014;9:58-65.

12. Patel NP, Sanyal M, Sharma N, Patel DS, Shrivastav PS, Patel BN. Determination of asenapine in the presence of its inactive 
metabolites in human plasma by LC-MS/MS. J Pharm Anal 2018;8:341-7.

13. Borkar AA, Gaikwad NJ. UV Spectrophotometric and RP-HPLC estimation of drug asenapine in tablet dosage form. Int J Pharm Sci Res 2016;7:3080-4.

14. Aneesh TP, Rajasekaran A. Stress degradation studies and development and validation of RP-HPLC method for the estimation of asenapine maleate. Int J Pharm Pharm Sci 2012;4:448-51.

15. Yadav BK, Sathish NK, Lamichhane M, Acharya A. A newer RPUFLC method development and validation of an anti-psychotic drug asenapine maleate in bulk drug and pharmaceutical formulation. Pharm Lett 2015;7:214-9.

16. Chhalotiya UK, Bhatt KK, Shah DS, Patel JR. Stability-indicating liquid chromatographic method for the quantification of the new antipsychotic agent asenapine in bulk and in pharmaceutical formulation. Sci Pharm 2012;80:407-17.

17. Karaca SA, Ugur DY. A stability indicating ion-pair LC method for the determination of asenapine in pharmaceuticals. J Chil Chem Soc 2017;62:3325-9.

18. Shyamala, Swarupa A, Anitha P. Validated stability-indicating RP-HPLC method for determination of asenapine. Indo Am J Pharm Sci 2018;5;4107-13.

19. Kalpana GL, Devalarao G, Raju MB, Praveenkumar T. Validated stability indicating high performance liquid chromatographic method for the quantification of asenapine. Int J Pharm Pharm Sci 2015;7:61-5.

20. Narke R, Mandlik S, Kapure S. Bioanalytical development and validation of Stability indicating RP-HPLC method for the estimation of asenapine maleate in plasma. Inventi Impact Biomed Anal 2015;1:5-8.

21. Ramadan NK, Mohamed TA, Fouad RM, Moustafa AA. Stabilityindicating high-performance liquid chromatography and thinlayer chromatography methods for the determination of cyclobenzaprine hydrochloride and asenapine maleate. J Plannar Chromat 2017;30:313-22.

22. Avasarala H, Jayanthi VR, Dinakaran SK. Fast and sensitive quantification of asenapine maleate by high-performance thin layer chromatography. Lat Am J Pharm 2018;37:330-3.

23. Caitlin M, Oscar P, Dan A, Diane MM, Norman WJ. Asenapine (Saphrisw): GC-MS method validation and the postmortem distribution of a new atypical antipsychotic medication. J Anal Toxicol 2013;37:559-64.
24. Ramadan NK, Mohamed TA, Fouad RM, Moustafa AA Potentiometric determination of asenapine maleate using PVC membrane and carbon paste ion-selective electrodes. Organic Med Chem Int J 2018;8:555726.

25. Aarelly K, Thimmaraju MK, Nerella R. Quantitative determination of asenapine in both bulk and formulations using neutralization titrations. J Appl Pharm Sci 2012;2:141-5.

26. Avasarala $\mathrm{H}$, Jayanthi VR. The development and validation of a spectrophotometric method for a novel anti-psychotic drug asenapine maleate. Int J ChemTech Res 2015;8:549-53.

27. Gandhimathi R, Vijayaraj S, Jyothirmaie MP. Method development and validation of UV-spectroscopic method for estimation of asenapine maleate in bulk and tablet formulation. Int J Med Chem Anal 2012;2:85-90.

28. Halima OA, Aneesh TP, Reshma G, Thomas NR. Development and validation of UV spectrophotometric method for the estimation of asenapine maleate in bulk and pharmaceutical formulation. Pharm Chem 2012;4:644-9.

29. Mrudulesh Y, Ravi Sankar P, Devadasu CH, Srinivasa Babu P. Development of a validated UV spectrophotometric method for the quantitative estimation of asenapine maleate in bulk drug. J Chem Pharm Sci 2013;6:227-30.

30. Maradiya JK, Goswami SS, Suhagia BN. A simple and reproducible estimation of some novel atypical antipsychotics by colorimetric method using bromocresol green as chromogen. Pharm Lett 2015;7:218-27.

31. Surekha ML, Swapna M, Swamy GK. New validated visible spectrophotometric methods for the estimation of triptans and asenapine maleate in bulk and in pharmaceutical dosage forms. Indo Am J Pharm Res 2013;3:4637-44.

32. Britton HTS. Hydrogen Ions. $4^{\text {th }}$ Ed. Chapman and Hall; 1952.

33. Job P. Spectrochemical methods of analysis. Wiley Interscience: New York; 1971. p. 346

34. Yoe JH, Jones AL. Determination of tungsten. Industrial and engineering chemistry. Anal Edition 1944;16:111.

35. International Conference on Harmonization of Technical Requirements for Registration of Pharmaceuticals for Human Use (2005) ICH Harmonized Tripartite Guideline, Validation of Analytical Procedures: Text and Methodology, Q2(R 1), Complementary Guideline on Methodology, ICH, London; 1996.

36. Miller JN, Miller JC. Statistics and chemometrics for analytical chemistry. $5^{\text {th }}$ ed. Prentice Hall, England; 2005. 